\title{
Land set-up systems in Italy: A long tradition of soil and water conservation sewed up to a variety of pedo-climatic environments
}

\author{
Giuseppe Lo Papa, ${ }^{1}$ Carmelo Dazzi, ${ }^{1}$ Sandor Némethy, ${ }^{2}$ Giuseppe Corti, ${ }^{3}$ Stefania Cocco ${ }^{3}$ \\ ${ }^{1}$ Department of Agricultural, Food and Forest Sciences, University of Palermo, Italy; ${ }^{2}$ Department of \\ Conservation, Faculty of Science, University of Gothenburg, Sweden; ${ }^{3}$ Department of Agricultural, \\ Food and Environmental Sciences, Università Politecnica delle Marche, Ancona, Italy
}

\begin{abstract}
Land set-up systems in Italy were and, in a few cases, still are integral parts of agricultural landscapes. The soils of Italy mirror a wide variety of climates and morphologies and derive from a great diversity of parent materials influenced by different soil temperature and moisture regimes. Furthermore, their development was influenced by several anthropogenic activities over time including land settings. Land set-up systems have been widely used throughout the Italian soilscape to regulate surface and underground water and to improve the physical soil features in a way that ensures mixed herbaceous and tree-crops cultivation. In recent times, new technologies have been introduced in agroforestry exploitation of the land, while the ancient but tested hydraulic soil systems have been abandoned. As a result, a great part of Italian soilscapes is prone to water erosion and floods, an unforeseen impact, which can be counterbalanced by good soil management practices. Moreover, new pedotechniques have been recently adopted, transforming soils and landscapes, but generating sometimes soil degradation issues. After presenting the main features characterizing Italian soils and landscapes, we describe all the historical land set-up systems adopted over time, highlighting their positive functions in terms of both soil conservation and agricultural production. We also emphasise the
\end{abstract}

Correspondence: Giuseppe Lo Papa, Department of Agricultural, Food and Forest Sciences, University of Palermo, Viale delle Scienze - Ed. 4, 90128 Palermo, Italy.

E-mail: giuseppe.lopapa@unipa.it

Key words: Land set-up systems; soilscapes; soil conservation; Italian cultural landscapes.

Acknowledgements: this paper and the research behind have been developed under the project Erasmus+ KA203 - Strategic Partnerships Sustainable Management of Cultural Landscapes agreement no. 20171-SE01-KA203-034570.

Received for publication: 28 October 2020

Accepted for publication: 3 November 2020.

CCopyright: the Author(s), 2020

Licensee PAGEPress, Italy

Italian Journal of Agronomy 2020; 15:1760

doi:10.4081/ija.2020.1760

This article is distributed under the terms of the Creative Commons Attribution Noncommercial License (by-nc 4.0) which permits any noncommercial use, distribution, and reproduction in any medium, provided the original author(s) and source are credited. importance of maintaining such land settings both as distinctive parts of cultural landscapes and strategies of soil conservation, and the need of developing new systems based on the principles of environmental sustainability.

\section{Introduction}

The landscape is defined as 'an area, as perceived by people, whose character is the result of the action and interaction of natural and/or human factors' (Council of Europe, 2000). Such actions and interactions strongly influence the 'soilscape' (a contraction of the terms 'soil and landscape'), namely the pedogenic cover of a specific landscape. For the soilscapes, in particular, the knowledge of the relationships among actions and interactions of natural and human factors is of paramount importance to preserve soil qualities and functions (Faber and van der Pol, 2006). In Italy, soil covers occur in a wide variety of climates and morphologies that include plains, hills, mountains, various volcanic formations, islands, marshes, and lacustrine environments, namely landforms with a great diversity of soil parent materials as well as temperature and moisture regimes (Costantini et al., 2013). Furthermore, anthropic activities over time had greatly influenced soil formation and development. Over the last decades, the characteristics of the historical evolution of different soilscapes and the evaluation of the long-term effects of soil management on landscape evolution and its socio-economic dynamics were important research topics on soil erosion and conservation in many European countries (Dazzi et al., 2019).

In this paper, after a general overview of the Italian pedo-environmental conditions, we introduce a historical excursus about the land set-up systems in Italy and a brief description of the most diverse land settings that were and, in a few cases, still are integral parts of the Italian soilscapes. Moreover, the environmental problems in connection with land use in large-scale farming to produce high-income cash crops is discussed.

\section{The Italian environment}

With an area of $302,072.84 \mathrm{~km}^{2}$, Italy is wedged between the Tyrrhenian and Adriatic seas as a characteristic spur-boot shaped narrow land, formed by consecutive orogenic processes since the Paleozoic, resulting in the mountain ranges of the Alps, the Dolomites, and the Apennines through the uplift of igneous and primarily marine sedimentary and metamorphic rocks. These processes can be traced from the Caledonian Orogeny (490-390 Ma, e.g. the Ordovician granites of the Alps) through the complex sedimentary and tectonic processes of the Mesozoic (251-66 Ma, e.g. 
Ladinian and Carnian carbonate platforms in the Dolomites or the pillow lava formations of Jurassic to Cretaceous age in Liguria), until the youngest processes of the Cenozoic (66 Ma to present), when the formation of the Apennine Mountains and the Alpine uplift continued. Based on the above outlined geological development, the Italian peninsula can be divided into seven specific geologic provinces such as the Alpine chain, the Po Plain, the Apennines, the Apulia foreland, the Calabrian-Peloritan arc, Sicily, and Sardinia (Bosellini, 2017). According to the European map of biogeographical regions (EEA, 2002, 2008), Italian territory belongs to three different regions: Alpine, Mediterranean, and Continental. Each of these regions presents a huge variability of climate, geology, morphology, and soils (Ibáñez et al., 2013) in which sometimes severe environmental degradation can be observed due to extensive agroforest exploitation of the soilscape.

\section{Morphology}

Italy is characterized by an alternation of mountainous, hills, and plains, with a predominance of hilly and mountainous slopes, accounting for $\approx 70 \%$ of the total area (Figure 1). Advantages arising from this topography because water, potentially the most important factor to increase crop yield in many of these environments, can easily be collected in reservoirs. On the other hand, water management appears to be a necessary condition for agroforest use of the land almost everywhere to avoid waterlogging in plain areas and erosion and landslides in the sloping areas.



Figure 1. Elevation map of Italy. 


\section{Climate}

Italy is characterized by a wide spectrum of climate types as the result of the combination among altitude, latitude, and position of the mountain chains (Table 1).

This spectrum of climate types strongly influences the variability of soil moisture and temperature regimes (Costantini et al., 2013). In terms of rainfall pattern, Italy has five precipitation regimes: i) Continental (Alpine system); ii) Pre-Alpine (Po valley); iii) Apennines (central and southern Apennines chain); iv) subcoastal (Tyrrhenian, Adriatic, and Ionian coast; central-southern pre-Apennines strips), and v) Mediterranean (south and island plains). Two main aspects characterize these precipitation regimes of the Italian territory: i) high year-to-year variability; and ii) concentration of rainfall into a limited number of intense rainstorms. The mean annual precipitation varies from $400 \mathrm{~mm}$ (Agrigento) to 3,800 $\mathrm{mm}$ (Musi Alps), with rainy days varying from 40-60 in southern Italy to 150 in the eastern Alps. Furthermore, orographic precipitation and orography enhanced precipitation should be considered for certain areas since they might have a considerable effect on erosion or water supply (Brunetti et al., 2002). Temperature also shows a wide variability. At national level, an average value of $13.3^{\circ} \mathrm{C}$ is recorded, but there is a difference of $14.5^{\circ} \mathrm{C}$ between the mean annual temperature of the coldest region (Valle d'Aosta, $3.6^{\circ} \mathrm{C}$ ) and that of the warmest one (Sicily, $18.1^{\circ} \mathrm{C}$ ) (ISPRA, 2015). Such variability justifies for a soil temperature regime that is cryic/frigid in the Alps and few areas of the Apennines; the mesic temperature regime prevails in northern Italy, throughout the Apennine, and in the Sardinian mountains, while the thermic regime characterizes the coastal areas of central Italy, Sardinia, and Sicily. The hyperthermic regime characterizes small areas of southern and western Sicily. Soil aridity index (SAI), expressed as the number of days the soil moisture control section (generally the $0-50 \mathrm{~cm}$ thickness) remains dry during the year, ranges from zero to $\approx 150$ and determines a soil moisture regime from udic to xeric; this latter borders toward aridic regime in the southern belt of Sicily. Based on the average data of rainfall, temperature, and evapotranspiration, two general aspects representative for all the Italian territory can be highlighted: i) areas with a water-surplus in autumn and winter, with the tendency to form shallow water-table in the plains and problems of excessive runoff on slopes, with consequent problems of erosion, landslides, floods, water pollution, siltation of the reservoirs, etc.; ii) areas with water-deficit in summer, particularly acute in sloping areas, which represent the most important limitation to plant production (Todorovic et al., 2007).

\section{Soil features and distribution}

Soils show properties influenced by the characteristics of the environment in which they evolve and, because of the high variability of environments in Italy they range from the least to the most evolved types (Figure 2). The Italian soils classified according to the Soil Taxonomy system (SSS, 2014) are shown in Table 2 in decreasing order of extension. Soils belonging to the orders of Gelisols and Oxisols are not listed since they are scarcely diffused in the country: fractions of $\mathrm{km}^{2}$ of Gelisols can be found only in

Table 1. Synoptic scheme of the Italian climatic types.

\begin{tabular}{|c|c|}
\hline Climate type & Location \\
\hline Hot-summer Mediterranean & The warmest areas of the coastal areas of southern Italy, Sicily, and Sardinia \\
\hline Warm-summer Mediterranean & The Tyrrhenian coastal belt; the southern belt of the Adriatic coast and the Ionian area \\
\hline Cold-summer Mediterranean & Hilly areas of the Tuscan-Umbrian-Marche pre-Apennines and southern Apennines \\
\hline Temperate subcontinental & Venice plain, Friuli Venezia Giulia plain, coastal area of the upper Adriatic, and the inland peninsula \\
\hline Temperate continental & Po valley and part of the Venice plain \\
\hline Temperate cool & Pre-Alps and the central axis of the Apennines \\
\hline Temperate cold & A strip of the Alps and the top areas of the main Apennine mountains \\
\hline Cold & Alpine areas above $2000 \mathrm{~m}$ of altitude \\
\hline Ice cap climate & Alps over $3500 \mathrm{~m}$ of altitude, with perennial snow \\
\hline
\end{tabular}

Table 2. Diffusion of the Soil Orders in Italy (data relating to 2013). Urban areas and water bodies are not considered.

\begin{tabular}{lcc} 
Soil Orders & $\mathrm{km}^{2}$ & $\%$ \\
Inceptisols & 146,228 & 49.55 \\
Entisols & 48,508 & 16.44 \\
\hline Alfisols & 38,416 & 13.02 \\
Mollisols & 35,712 & 12.10 \\
\hline Andisols & 9704 & 3.29 \\
Vertisols & 8060 & 2.73 \\
\hline Spodosols & 7500 & 2.54 \\
Ultisols & 741 & 0.25 \\
\hline Histosols & 195 & 0.07 \\
Aridisols & 33 & 0.01 \\
\hline Total & 295,097 & 100.00 \\
\hline
\end{tabular}


the highest peaks of the Alps where there is permafrost, while Oxisols are mainly represented by palaeosols with very narrow diffusion and restricted surface area.

Inceptisols cover almost half of the Italian territory and are present with different proportions in all the regions. Their ubiquity can be attributed to the fact that the majority of the Italian soilscape has been, and is, affected by accelerated processes of erosion, often due to human activity.

Entisols are traditionally present in two typical morphologies: on steep slopes (Orthents) or lowland (Fluvents). The former are young soils due to accelerated processes of erosion, while the latter are rejuvenated by alluvial deposition processes. From a pedolog-

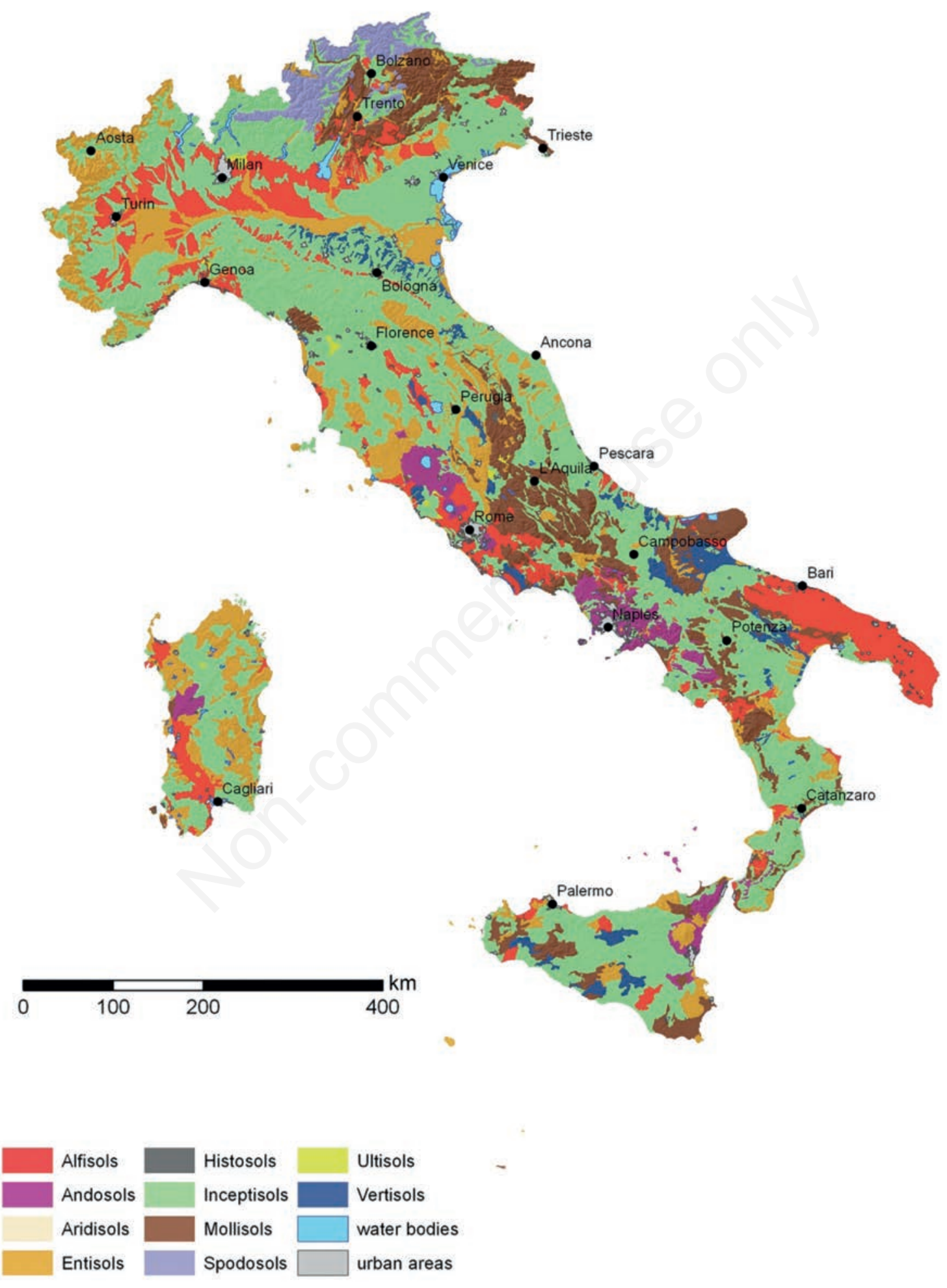

Figure 2. Soil map of Italy. Soils are mapped at the Soil Order level according to the Soil Taxonomy (from Costantini et al., 2013). 
ical point of view, humans must be considered a forming force that causes soil changes through different interventions: irrigation, reclamation, as well as relief and drainage modifications that could change soil moisture regimes. Therefore, the present soil distribution reflects past farming practices, intensive exploitation of soils and monoculture, improper forest management, and abandonment of soil set-up systems which have initiated land degradation in many regions (Piccarreta et al., 2006; Corti et al., 2013). Particularly in the widespread mountainous environments, which includes many Italian regions, the mechanization has triggered erosion processes (Bazzoffi and Jakab, 2006; Bazzoffi et al., 2011), producing heavy soil losses and reducing the thickness of the solum. Erosion has consequently induced a slow process of pedogenetic involution that has transformed previous soils into Entisols, i.e. mineral soils that have not differentiated into distinct diagnostic horizons, do not show any profile development other than an A horizon, and unaltered from their parent material, which can be unconsolidated sediment or rock. This specific degradation process, named Entisolization (Dazzi, 1995; Costantini and Barbetti, 2008), is considered opposite to those pedogenetic processes that drive soils to differentiate diagnostic horizons and develop the profile. In some cases, especially in the past, remodelled and abandoned slopes with parent materials made of finegrain textured marine sediments have also changed Inceptisols into Entisols, as expressed by the formation of calanchi, the Italian word used to refer to badlands (Cocco et al., 2015). In other cases, Entisols are characterized by the presence of an anthropic epipedon, namely a horizon formed in human-altered material (HAM, i.e. soil material significantly altered by intentional human activity) or human transported material (HTM, i.e. soil material transported by intentional human activity) [The key feature of anthropic epipedon is that it forms as a result of intentional human alteration (but not simply by common agricultural practices like plowing or amendment distribution). Its landscape setting (such as a raised surface due to filling) and/or presence of human artifacts are key characteristics.]. Soils with such epipedon are generally called anthropogenic soils and are mainly present in Sicily and Apulia (Dazzi et al., 2009; Lo Papa et al., 2011; Zdruli et al., 2014), in areas characterized by large-scale farming (Lo Papa et al., 2018).

Alfisols are present where environmental conditions favour the leaching process. Among Alfisols, particular attention should be paid to the Rhodoxeralfs, the Mediterranean Terra Rossa of the old soil classifications, which are particularly widespread on the Apulian and Sicilian carbonate plains.

Mollisols prevail in central and north-eastern Italy mainly on carbonate substrates (limestones and dolomites). In southern Italy, they appear in flat morphology environments with herbaceous or shrub vegetation, where organic matter tends to accumulate as a consequence of the prolonged summer stasis of microbial activity caused by the water shortage and high temperature.

Andisols characterize all Italian volcanic areas of centralsouthern Italy and of the islands. Their properties are strongly affected by the substrate and climatic characteristics (Dazzi, 2007) and, in some cases, they are subject to erosion too (van der Knijf et al., 2000; Corti et al., 2013).

Vertisols, the soils with cracks that open and close periodically, are mostly present in central and southern Italy on flat or slightly sloping morphologies. They usually develop from sediments (marine, fluvial, and glacial), have a clayey texture and, depending on the different environmental features, they can show accumulation of carbonate or gypsum or, in some southern coastal areas, soluble salts deriving from irrigation with unsuitable water.
Because of their content of expandable minerals, an additional soil threat due to the ongoing climate change leading to a further reduction of precipitation might affect also Inceptisols that started to be affected by the process of Vertisolization. Because long-standing plants are not able to survive on Vertisols since their roots are massively broken during crack formation, there is the need to increase our knowledge on these soils to be able to develop appropriate soil management systems and identify crop varieties that are suitable for this soil type.

Spodosols prevail in north-eastern Italy, generally above 2000 meters of altitude under coniferous vegetation.

Ultisols are in spot areas with prevalence in central and northern Italy.

Histosols are present where the morphological, climatic, and vegetation characteristics have allowed, over time, organic matter accumulation. They prevail in the Alpine area, but are also present along the Apennine chain, and are largely made up of fibrist and saprist horizons.

Aridisols are shallow soils present in spot areas in the south coast of Sicily.

\section{Land use}

In the year 2016, the agrarian and forestry surface in Italy was nearly 23.1 million ha (ISPRA, 2018), corresponding to $76.4 \%$ of the national territory. Within the agrarian surface $(\approx 12.6$ million ha, $41.7 \%$ of the territory), arable land accounted for $56.7 \%$, followed by permanent meadows and pastures $(25.6 \%)$, tree orchards $(17.5 \%)$, and family gardens $(0.2 \%)$. Cereals are the main crops of arable land, with wheat as the most diffuse one (mainly in the Po valley, Apulia, Metapontum, interior hilly land of Marche, Maremma plain in Tuscany, Latium, Sicily, and Sardinia), followed by maize (mainly in Lombardy, Veneto, Emilia-Romagna, Latium, and Campania). Barley is mostly cultivated in Sicily, Sardinia, and Apulia, while rice is mainly present in Piedmont and Lombardy. Arable land also comprises areas where cereals are in rotation with crops like potato, tomato, cabbage, cauliflower, artichoke, endives, onions, etc.. Productions of specialized crops around the larger urban centres and those located in coastal areas or in the irrigated plains of southern Italy, sometimes under greenhouses, must also be mentioned. Forage crops are made on natural pastures mostly located in the mountainous areas of Alps and Apennines and in the more disadvantaged internal areas of the south and the isles, where it is not possible to grow other crops due to the shallow soils and aridity. Permanent grassland and rotational leys are mainly located in the best plain areas of the northern and central Italy, often under irrigation. To a less extent, rotational leys are cultivated in rain-fed arable land of southern Italy, in semi-arid environments. In arable land rotations, the cultivation of catchcrops is rather diffused, representing often the main source of forage for animal breeding. Among tree crops, olive is cultivated most extensively, with $77 \%$ of the olive grows in southern and isle areas, and $23 \%$ in the central-northern part of the Country. Grape is the second tree-crop, mainly cultivated in Sicily, Apulia, Veneto, Piedmont, and Tuscany. Fruit tree orchards such as apple, peach, and pear are located in northern Italy, particularly in EmiliaRomagna, Veneto, and Trentino Alto Adige regions. Citrus groves are spread mainly in southern Italy, and particularly in Sicily, orange being the most extensively cultivated crop $(60 \%$ of total citrus production); lemon and clementine account for $38 \%$ of the citrus production, while other species account for $2 \%$. Almond is 
cultivated primarily in Apulia and Sicily, while nuts are cultivated mainly in southern regions, with consistent cultivation also in Liguria and Piedmont.

Woodlands cover 10.5 million ha, corresponding to $34.7 \%$ of the national territory (INFC, 2005). The most wooded areas are in Liguria and Trentino, while the least wooded regions are Apulia and Sicily. The relatively small extension of woodlands for a country having more than $70 \%$ of mountainous and hilly areas depends on the fact that several hilly areas that could be advantageously left to forest are used for arable crops, especially cereals, while in other cases they are used as poor natural pastures. Furthermore, forest fires due to summer drought have also contributed to reducing forest diffusion, especially in the south.

We are aware that the information outlined above is insufficient to elucidate the very complex agro-environmental situation of the Italian territory, but we assume that the most critical points illustrated above may give a suitable description of the general situation, especially on the fact that many aspects of soil degradation in Italy are strictly connected to crop systems, climate, and water management.

\section{Land set-up systems in Italy}

\section{Historical excursus}

The variety of the above described Italian land use systems and environments are not only the result of the interaction of pedogenic forces sensu Jenny (1941) but also of a deep anthropic influence and utilization of the soilscapes that dates back to 4000 years before present (Corti et al., 2013). In fact, the first great transformation of the Italian soilscapes dates back to three important civilizations: the Greek, the Etruscan, and the Roman, which were profoundly tied to soils for their agricultural economics (Corti et al., 2013). During Greek domination, irrigation ditches and conduits were introduced but, despite their efforts, the Greeks did not conceive specific techniques to combat soil erosion, which caused the decline of soil quality (Brevik and Hartemink, 2010). However, they left us an ensemble of man-made landscape mosaics, which were denominated Mediterranean gardens (Sereni, 1986), that were rather widespread in southern Italy. Greeks organized the rural landscape into geometric fields that were ploughed according to regular stripes, and properties had irregular borders but with geometrically subdivided fields cultivated by applying crop rotation, orchards, and isolated tree fruits, with drywall terraces, pastures, small woods, and a network of ditches and conduits with sparse wells. These structures are nowadays considered as the first Italian soil system organization that still occurs in a few sites of the southern territory.

Instead, in central Italy, Etruscans were aware of the damages due to soil erosion and, before seeding, they prepared soil with hydraulic techniques able to regulate the outflow of run-off; this can be considered the most ancient and innovative approach in soil reclamation for the Italian territory. Romans at the beginning coexisted with the Etruscans and later succeeded them, also improving the rural land organization by introducing hedgerows, drywalls, and ditches to separate countryside properties and to reclaim territories. Problems linked to incorrect land and soil management started during the Roman period and are nowadays considered among the reasons for the fall of the Western Roman Empire (Rifkin, 2000).

Historians maintain that Rome fell due to the decadence of its leaders, the corruption of its emperors, and the superior military tactics of the barbaric invaders; however, an additional cause of the decline is considered to be the slow process of soil fertility loss with consequent reduction of productions (Rifkin, 2000). The reduced agricultural production resulted in difficulties to maintain the lifestyle of Roman citizens and their army, but also to supply enough wealth to maintain the great infrastructures of the Empire (roads, aqueducts, monuments, etc.). The progressive decline of soil fertility started just when Rome began to depend on agriculture as an alternative to its unsuccessful conquests. During the final period of the Empire (5 $5^{\text {th }}$ century A.D.), agriculture gave over 90 $\%$ of public income, and products from the land were of vital importance (James et al., 2014). Romans, therefore, tried to intensify agricultural production to provide food for citizens and soldiers, but this led to further exploitation of the already exhausted land and caused a slow depopulation of the country that lasted for the whole period of the Empire. Weakened by the depletion of its energy system, the Empire then collapsed (476 A.D.).

After more than one millennium of technological silence, it was during the XVIII century that agronomists started to face erosion and developed a variety of land settings suitable for many pedoclimatic and geomorphic conditions (Garcia-Ruiz, 2010). As reported by Cosimo Ridolfi in Giornale Agrario Toscano in 1830, solutions to combat hilly soil erosion were studied and named colmate di monte (filling in mountain) and unita a spina. These land settings have characterized Tuscan landscape till the end of the last century (Landi, 1984, 1989), but occasionally they can be found even nowadays. Since then, mainly in the XIX century, many other land set-up systems were developed to reply to the various Italian soil-climate-production combinations, in many cases associated with programmes of land reclamation like that occurred between 1900 and 1914 (Serpieri, 1948). More than 100 years ago, Vittorio Niccoli (1905) stressed that the purposes of the land set-up systems were to: i) expose the maximum soil surface to the atmospheric actions; ii) make the soil soft and porous to facilitate the development of the roots; iii) maintain the soil fresh by storing the rainwater and ensuring slow evaporation so that plants have, in the different stages of their development, a sufficient amount of available water; iv) incorporate and distribute the materials brought into the soil with fertilization; v) intensify the chemical and biological reactions for which transformations of materials and absorption of atmospheric gases and vapours take place; vi) bring back to the surface fertilizing elements from the lower layers; vii) destroy all the weeds that are not part of the useful cultivation of the fields; viii) destroy insects or other harmful animals living in the soil.

Some of these purposes, expressed in an ancestral form, are no more valid nowadays if one considers: i) the evolution of the knowledge on the soil systems; ii) the evolution of the soil related technology and of the land set-up systems; iii) the necessity to assure the environmental sustainability and soil security (Dazzi et al., 2019; Dazzi and Lo Papa, 2019).

Starting from the first years of the $20^{\text {th }}$ century, some land setup systems have been widely used throughout the Italian soilscape to regulate surface and underground water and to improve the physical soil features in a way that ensured mixed herbaceous and tree-crops cultivation. Despite all these good past lessons, since the end of the World War II to the 1980s, agroforestry exploitation has rapidly evolved, leading to radical changes of socio-economic conditions, farm structures, and soil and crop management, sometimes leading to the modification of the natural features of the environment and to a perverse degradation cycle of the fundamental resources. New technologies have been introduced in agro-forestry exploitation of the land, while most of the ancient but tested 
hydraulic soil systems have been abandoned. As a result, a great part of the Italian soilscapes is prone to water erosion and floods (Dazzi and Lo Papa, 2013; Borrelli et al., 2017) and good soil management is even more necessary. In this context past solutions and experiences must be known.

\section{Land set-up systems in plain areas}

The main land set-up systems used in the flat Italian soilscape before the widespread application of mechanization in agricultural management are synthetically described below.

\section{Proda}

The proda system was common in the flat areas of central Italy characterized by fine-textured soils. Fields were around $2000 \mathrm{~m}^{2}$ $(\approx 60-80 \mathrm{~m}$ long and $15-30 \mathrm{~m}$ wide, depending on the soil permeability), and were limited by $60 \mathrm{~cm}$ deep lateral trenches with roughly rectangular section and grassed rim. Along the field borders, a vine row supported by wood stacks or trees (maples and/or ashes) placed at $\approx 0.8-1 \mathrm{~m}$ from the trench creates a sort of strip called proda (Figure 3). Nowadays this land setting has been almost abandoned due to the costs required to maintain the system. To favour agricultural mechanization, vine rows were removed and the fields merged.

\section{Piantata}

The piantata system was common roughly in the same areas of central Italy where proda system was applied, but on fine-loamy textured and thick soils. Fields were around 2000-3500 $\mathrm{m}^{2}$ (60-80 $\mathrm{m}$ long and 30-35 $\mathrm{m}$ wide) and, in between, showed a hope-chestshaped strip 4-5 m wide and 30-70 cm maximum high, called piantata, hosting a tree-row usually made by vines supported by maples or mulberries (Figure 4). Nowadays, such a system has been adapted to mechanized agriculture by removing the tree rows, levelling, and merging the fields.

\section{Cavalletto}

The cavalletto system was quite common in northeastern Italy where fine-textured soils characterized flat areas. Fields were around 2500-3500 $\mathrm{m}^{2}$ ( $\approx 80-100 \mathrm{~m}$ long and 30-35 $\mathrm{m}$ wide) with a hope-chest-shaped surface with a maximum height of $60-70 \mathrm{~cm}$.

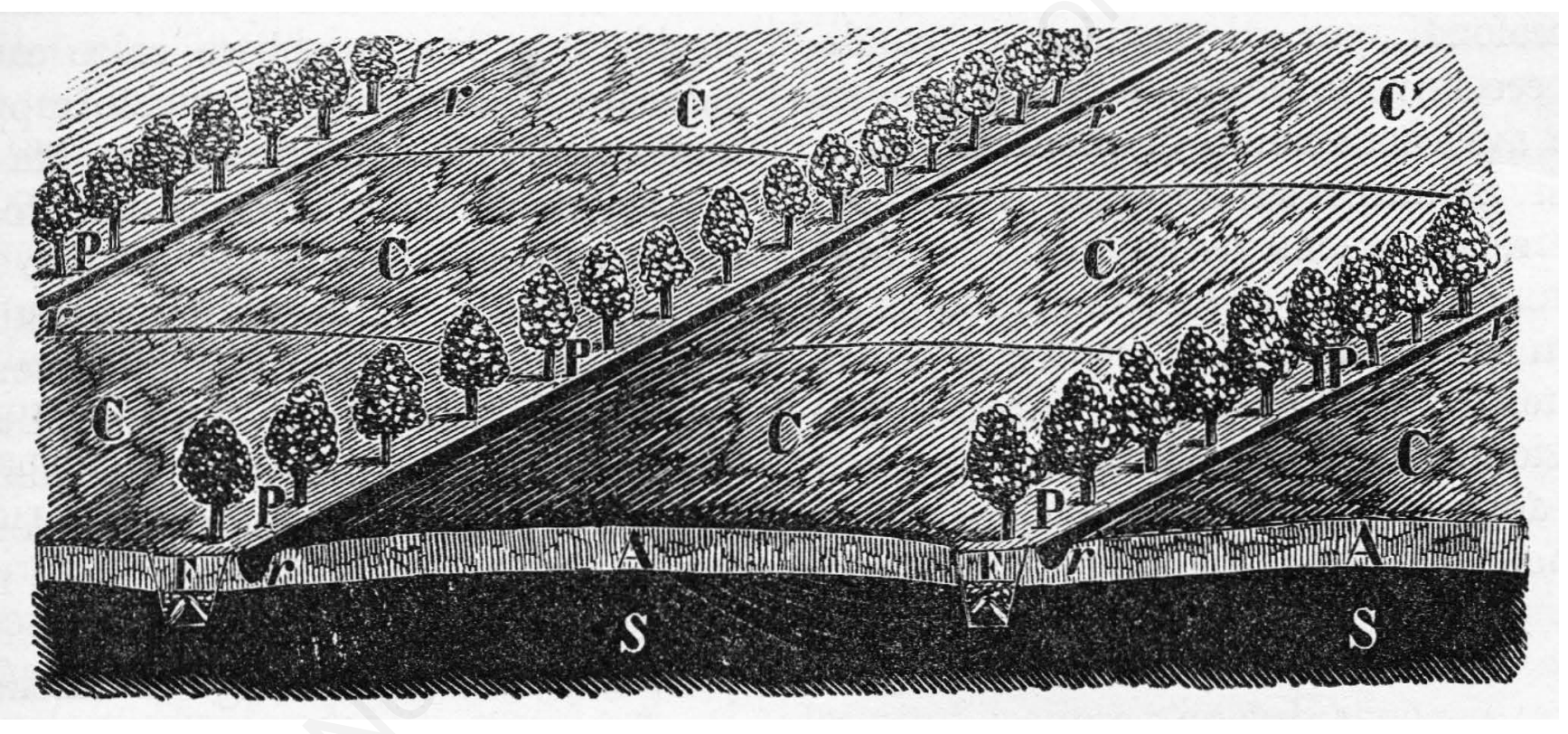

Figure 3. Schematic illustration of the proda system. From Enciclopedia agraria italiana (Cantoni, 1882).



Figure 4. Schematic illustration of the piantata system. 
In between the fields, a hope-chest shaped strip 4-6 m wide, called cavalletto, hosted a row of vines supported by maples, which were planted along the row 4-6 $\mathrm{m}$ one from another (Figure 5). Cavalletto, as well as piantata system, has been used mainly to improve the soil drainage and to protect crops from strong winds. Also the cavalletto system has been adapted to mechanized agriculture by removing the tree rows, levelling, and merging the fields.

\section{Cavino}

Similar to cavalletto, the so-called cavino system was common in northeastern Italy on flat areas with fine-textured soils. Fields were around $2500-4000 \mathrm{~m}^{2}(\approx 60-100 \mathrm{~m}$ long and $35-50 \mathrm{~m}$ wide), with the ridge of the hope-chest-shaped surface perpendicular to the long side of the 1-1.5 m high field. A 4-5 m wide strip hosting a row of trees separated the fields. A trench (locally called cavino) ran along the long side of the fields. Also the cavino system has been adapted to mechanized agriculture by removing the tree rows, levelling, and merging the fields.

\section{Larghe}

Larghe was a common system for the relatively well-drained lands in northern and central Italy, particularly in fine to very fine textured soils with a shallow natural height to discharge the water in excess that had been increased because of artificial drainage systems. Fields, free from any tree row, were $200 \mathrm{~m}$ long and $40 \mathrm{~m}$ wide $\left(8000 \mathrm{~m}^{2}\right)$, with a hope-chest-shaped surface. In the long side of the fields, water was collected by trenches and channelled to bigger trenches running along with the head of the fields. This system was easily adapted for the requirements of mechanization without particular modifications.

\section{Land set-up systems in hilly areas}

Several land set-up systems were developed in the hilly Italian soilscape. The main aim was to reduce the run-off and to increase the water infiltration rate. These goals were not always achieved.

\section{Girapoggio}

Girapoggio (meaning going down around the hill slope) is an extensive and expensive maintenance system, which characterizes some hilly areas with a moderate slope where Inceptisols prevail. The trenches were $20-30 \mathrm{~cm}$ deep and $30-50 \mathrm{~cm}$ wide and run along the contour lines with a slope of $\approx 1.5-3 \%$ (Figure 6 ).

\section{Cavalcapoggio}

Cavalcapoggio (meaning straddling the hill) is a set-up system for not very steep slopes (no more than $25-30 \%$ ). The slope is divided into 25-30 meters wide strips in which rows of trees and/or soil tillage follow the contour lines on the hump and the lines of maximum slope on the sides.

\section{Spina}

The unita a spina (meaning looks like a herringbone) system was developed in Tuscany at the beginning of the $19^{\text {th }}$ century as an evolution of the girapoggio system. It aimed to intensify the cultivation in hilly soilscapes with less than $30 \%$ slope mainly characterized by clayey Inceptisols (Figure 7).

\section{Rittochino}

Rittochino (meaning according to the maximum slope) is a common system on hilly soilscapes in central and south Italy characterized by clayey Entisols, Inceptisols, and Vertisols. In the rittochino system, soil tillage is made along the maximum slope. This allows for rapid water flow along the slope and low penetration of water into the soil, but the system unfortunately favours soil erosion. Originally, a row of trees separated the fields (Figure 8), but with the advent of intensive agriculture, the fields were joined and trees eliminated.

\section{Terracing}

Terracing is particularly adopted in areas with steep slopes, as it happens in vast Alpine and Apennine areas or hilly silty/clayey areas. Drystone walls support the fields, whose width is a function of the slope: higher the slope, smaller the field width, and vice versa (Figure 9). Particular terraced areas are gradonamento, ciglionamento, and lunetta.

\section{Gradonamento}

Gradonamento (meaning forming the step) is an extensive system diffused in the steep slope of hills and low mountain rocky areas mainly in central and southern Apennines, where it is functional to the creation of small plain surfaces for the pasture and/or extensive orchards (Figure 10). A green wall made by perennial herbs supports the fields.

\section{Ciglionamento}

Ciglionamento (meaning embankment) is rather common in



Figure 5. Schematic illustration of the cavalletto system. 
northern Italy on the hilly loamy and clay-loam Inceptisols developed on sandstone and conglomerate. This system was developed on slopes that do not exceed $40 \%$ inclination; as it happens for the gradonamento, a green wall made by perennial herbs supports the fields, whose width is a function of the slope.

\section{Lunetta}

A single terrace with a roughly semi-circular shape supported by a drystone wall and sustaining a single tree (olive, almond, carob) is a lunetta (meaning small moon). It is diffused in hilly areas of southern Italy where calcareous or gypsiferous Entisols prevails. Anyway, year after year, such a set-up system is on the way to be abandoned.

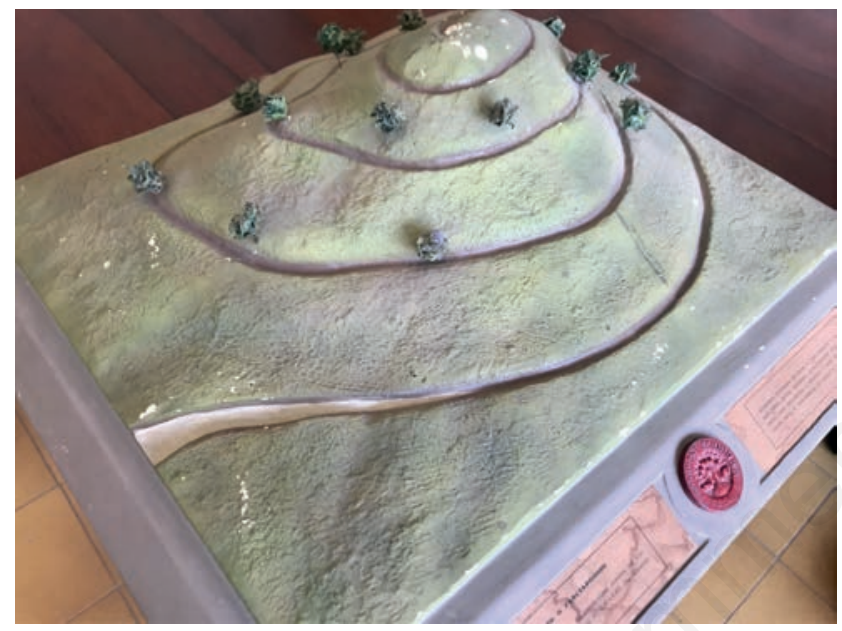

Figure 6. Didactic 3D plastic model of the girapoggio system. The model is kept at the Department of Agricultural, Food and Forest Sciences - University of Palermo.

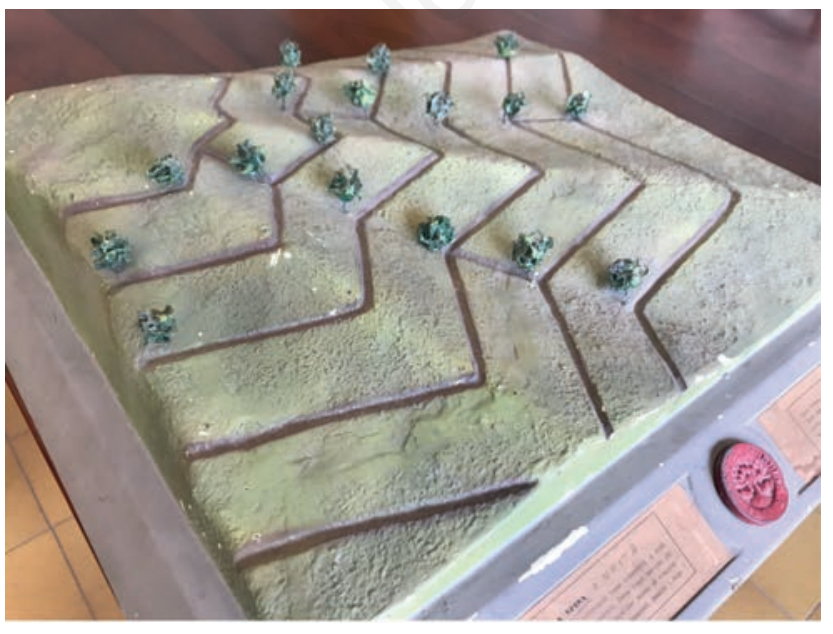

Figure 7. Didactic 3D plastic model of the spina system. The model is kept at the Department of Agricultural, Food and Forest Sciences - University of Palermo.

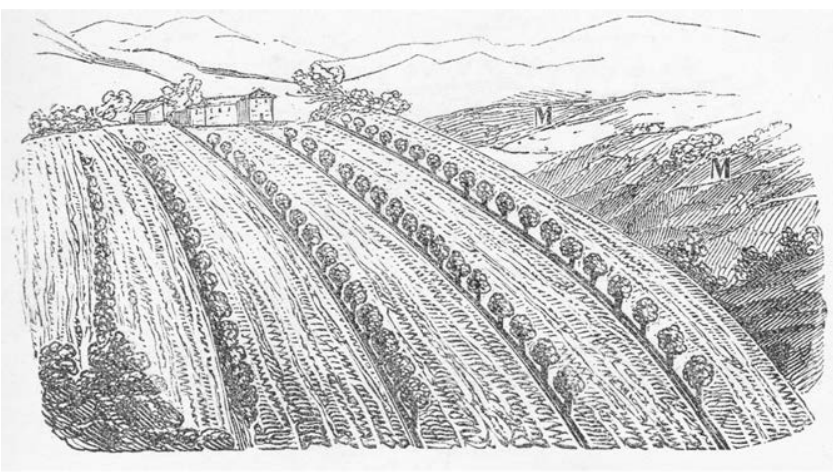

Figure 8. Schematic illustration of the rittochino system. From Enciclopedia agraria italiana (Cantoni, 1882).



Figure 9. Winter vision of terraces made to stabilise an alluvial fan and areas with incoherent detritus of glacial origin. Terraces face southern exposure, span from $\approx 1010$ to $\approx 1050 \mathrm{~m}$ above sea level, and are cultivated with grape. Morgex, Aosta, Italy.

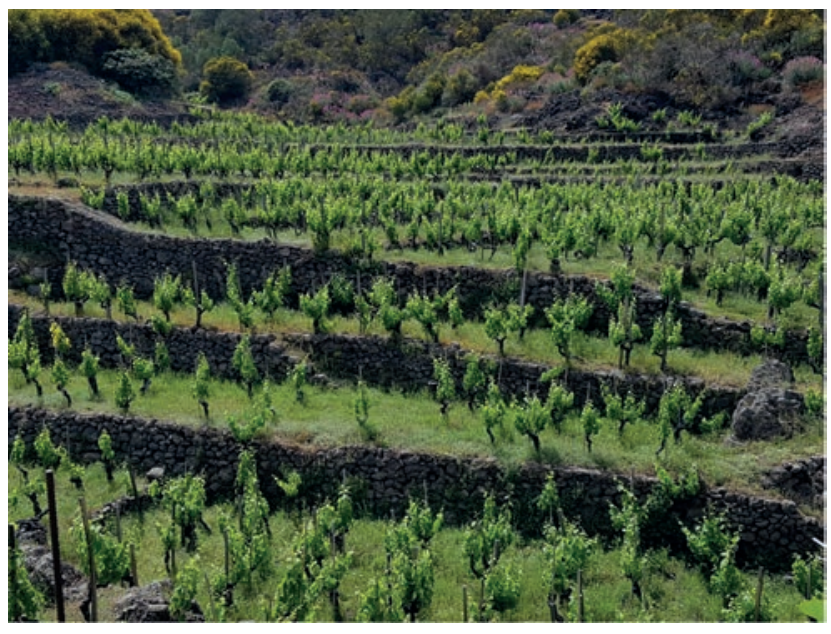

Figure 10. Terraced vineyards supported by stone walls in the north-eastern part of Etna Volcano, Sicily, Italy. 


\section{Land set-up systems and operations in intensive mecha- nized large-scale farming}

Over the last twenty years, new land set-up systems and operations have spread out in some areas of south Italy (Apulia and Sicily in particular) where land use changes from traditional crops (durum wheat, olive, almonds) to table grapes were driven by the awareness that the increase of active and total $\mathrm{CaCO}_{3}$ content fits well with vine's calcium $(\mathrm{Ca})$ requirements. This, in turn, has led to a substantial increase in the capital income deriving from table grape cultivation (Dazzi et al., 2019; Costantini and Barbetti, 2008).

The set-up system used in Apulia is called frantumazione (meaning crushing) and over the last two decades has expanded to cover $\approx 20,000$ ha. It consists of breaking and grinding calcareous rocky sub-layers and rock layers, mixing them with the remaining soil, and surface levelling (Zdruli et al., 2014). Frantumazione produces anthropogenic soils (Figure 11) with low content of soil organic matter and a substantial reduction in the total $\mathrm{C}$ and $\mathrm{N}$ content over 15 years immediately following land use change. Positive effects of frantumazione include increasing the rooting depth and the content of available $\mathrm{Ca}$ and skeleton, which favours drainage. In Sicily, frantumazione accounts for some 20,000 ha and is spread across the western area of the island, on Entisols or Alfisols derived from calcareous and calcarenitic substrata.

In central and eastern areas of Sicily where Mollisols, Alfisols, Vertisols, and Inceptisols prevail, farmers create anthropogenic soils by covering the original soils with a 70-90 cm of HTM made of marly limestone, a soft rock made of 70\% limestone and 30\% clay. Afterward, the soils covered with HTM are ploughed up to a depth of $100 \mathrm{~cm}$ with a mouldboard one-furrow plough, obtaining soils with a double sequence of horizons at an oblique angle to the soil surface. Regarding the features of these soils, they show an anthropogenically disturbed deep profile (Figure 12) with a very light topsoil colour, a very high content of both total and active carbonates, and a low organic carbon content that unevenly decreases with depth. In this situation, a high-grade mechanization of the vineyard and the lack of practices to mitigate water runoff can accelerate rill and gully erosion during high-intensity rainfall events, reducing soil fertility and organic carbon stock, as well as causing downstream inundations, muddy floods, and pollution (Blavet et al., 2009; Dazzi and Lo Papa, 2016).

\section{Conclusions}

The Italian peninsula shows different morphological regions that are characterized by different soilscapes. The interaction of many soil forming factors like climate, parent material, morphology, and human activity created a rich pedodiversity, which needs a different and focused soil management to save and protect soils.

While in the past, Italian farmers managed soils respecting their physical and chemical fertility through the adoption of appropriate land set-up systems, during the last century soil protection

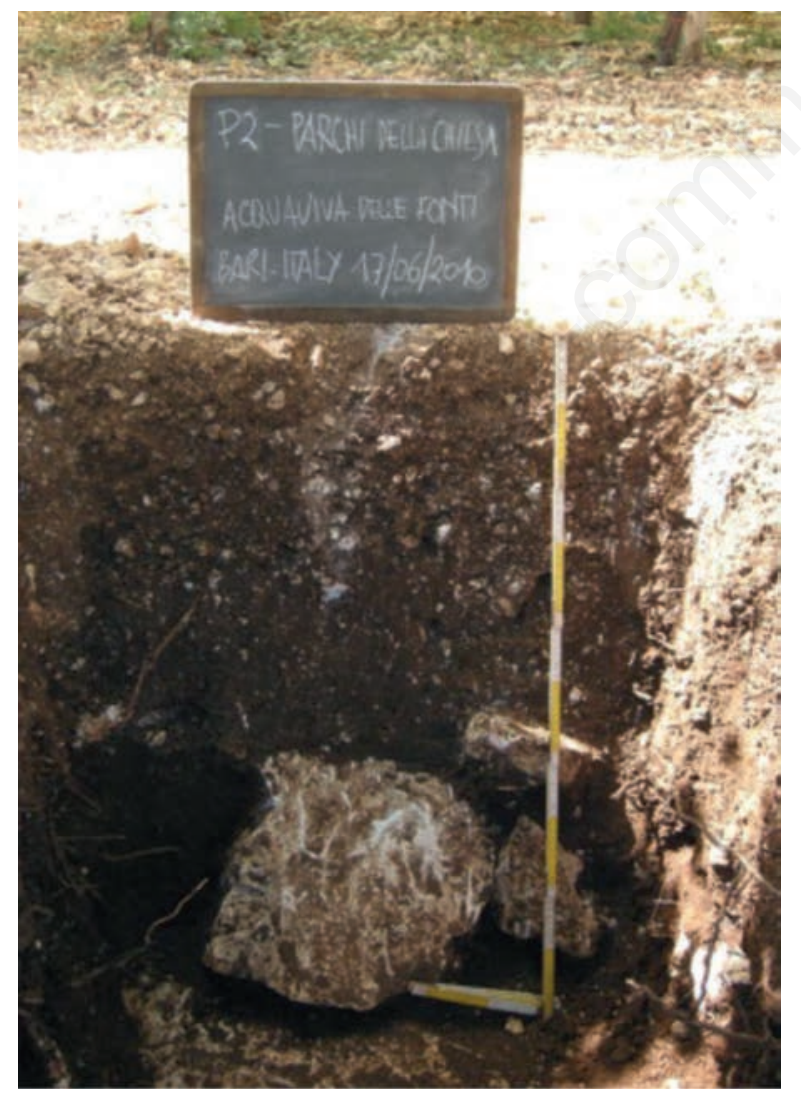

Figure 11. Profile of anthropogenic soil generated by frantumazione technique (from Zdruli et al., 2014).

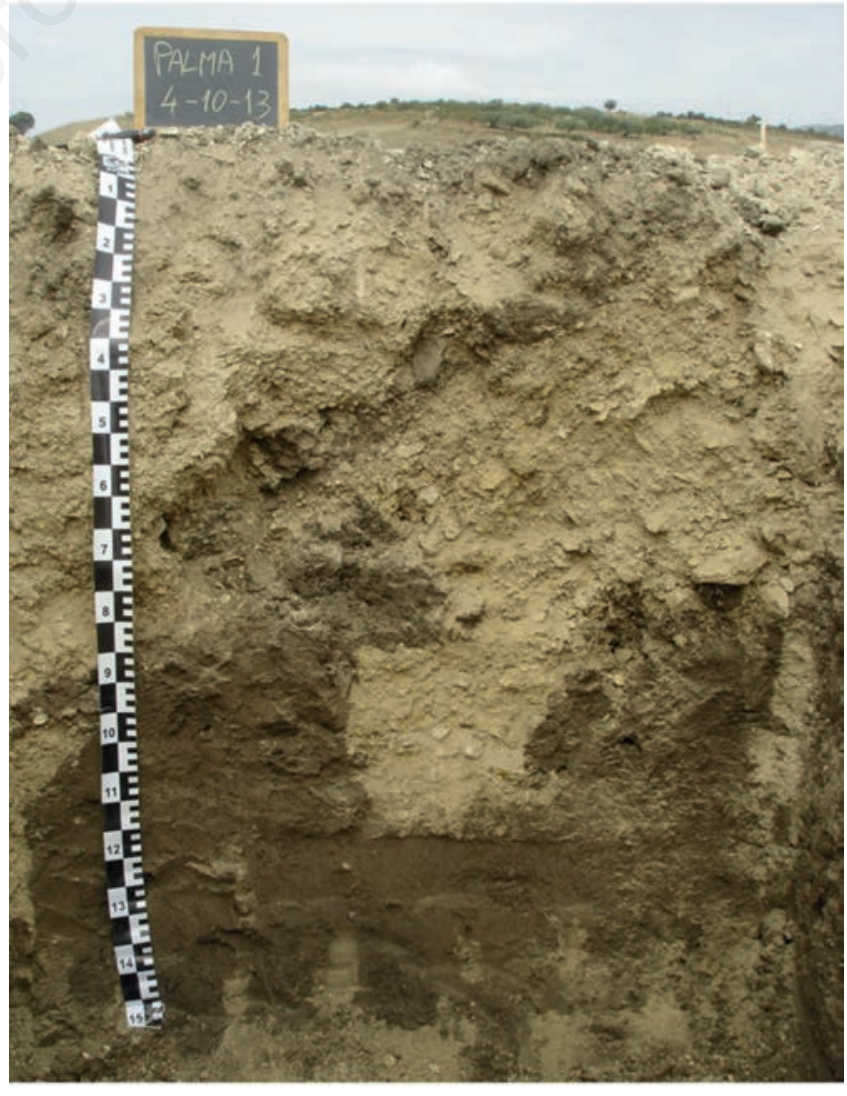

Figure 12. Profile of anthropogenic soil generated by complex pedotechnique (from Lo Papa et al., 2018). 
and conservation practices have been drastically reduced and frequently abandoned. As a consequence, re-shaped slopes have been neglected, soil set-up systems have been erased, and frequently rills and gullies threaten the soil thickness in hilly and mountain areas. Furthermore, the abandonment of highland farming consistently reduced the protection from human-made conservation measures on the denuded farmland as well as on the maintenance and amelioration of natural pastures. Consequently, water management is of utmost importance, especially for clay soils on sedimentary parent materials, which have negative physical properties, restrictive of the range of crops that can be advantageously cultivated. Unavoidable limitations to agroforestry exploitation are due even to the extensive areas of shallow soils on hard rock parent materials (limestone, sandstone, etc.), which are largely extended in southern Italy and mountainous areas.

A new approach to land set-up systems and a launch of integrated programmes for soil conservation that takes into consideration soil and landscape is mandatory to mitigate, stop or prevent soil erosion especially also in the context of climate change impacts.

\section{Highlights}

- Italy shows different morphological regions that are characterized by different soilscapes.

- Historical land set-up systems are distinctive constituents of the Italian cultural landscapes.

- Land settings have been adopted over time to protect soil and increase agricultural production.

- New pedotechniques have been recently adopted in large scale farming with no consideration of soil conservation.

- Maintenance of historical land set-up systems and development of new systems is needed.

\section{References}

Bazzoffi P, Ciancaglini A, Laruccia N, 2011. Effectiveness of the GAEC cross-compliance standard short-term measures for runoff water control on sloping land (temporary ditches and grass strips) in controlling soil erosion. Ital. J. Agron. 6(s1):1024.

Bazzoffi P, Jakab G, 2006. Land levelling. In: Boardman J, Poesen $\mathrm{J}$ (Eds.), Soil erosion in Europe. Wiley, Chichester, UK.

Blavet D, De Noni G, Le Bissonnais Y, Leonard M, Maillo L, Laurent JY, Asseline J, Leprun JC, Arshad MA, Roose E, 2009. Effect of land use and management on the early stages of soil water erosion in French Mediterranean vineyards. Soil Tillage Res. 106:124-36.

Borrelli P, Robinson DA, Fleischer LR, Lugato E, Ballabio C, Alewell C, Meusburger K, Modugno S, Schütt B, Ferro V, Bagarello V, Van Oost K, Montanarella L, Panagos P, 2017. An assessment of the global impact of $21^{\text {st }}$ century land use change on soil erosion. Nat Commun 8:2013.

Bosellini A, 2017. Outline of the geology of Italy. In: M. Soldati, M. Marchetti (Eds.), Landscapes and Landforms of Italy. pp. 21-27 World Geomorphological Landscapes. Springer, Cham.

Brevik EC, Hartemink AE, 2010. History, philosophy, and sociology of soil science. In: V. Squires, W. Verheye (Eds.), Encyclopedia of life supporting system (EOLSS). UNESCO EOLSS Publishers, Oxford, UK.

Brunetti M, Maugeri M, Nanni T, Navarra A, 2002. Droughts and extreme events in regional daily Italian precipitation series. Int. J. Climatol. 22:543-58.

Cantoni G, 1882. Enciclopedia agraria italiana, Volume II. Unione Tipografico-Editrice, Torino, Italy.

Cocco S, Brecciaroli G, Agnelli A, Weindorf D, Corti G, 2015. Soil genesis and evolution on calanchi (badland-like landform) of central Italy. Geomorphology 248:33-46.

Corti G, Cocco S, Brecciaroli G, Agnelli A, Seddaiu G, 2013. Italian Soil Management from Antiquity to Nowadays. Soils of Italy, Chapter 9. In: Costantini E, Dazzi C (Eds.), The Soils of Italy. World Soils Book Series. Springer, Dordrecht, Germany.

Costantini E, Barbetti R, 2008. Environmental and visual impact analysis of viticulture and olive tree cultivation in the province of Siena (Italy). Eur. J. Agron. 28:412-26.

Costantini EAC, Fantappié M, L'Abate G, 2013. Climate and Pedoclimate of Italy. In: E. Costantini, C. Dazzi (Eds.), The Soils of Italy. World Soils Book Series. Springer, Dordrecht, Germany.

Council of Europe, 2000. European Landscape Convention. European Treaty Series - No. 176. Available from: https://www.coe.int/en/web/conventions/full-list/-/conventions/rms/0900001680080621

Dazzi C, 1995. L'erosione "genetica" dell'ecosistema suolo. pp 197-202 in Atti del Convegno Nazionale SISS "Il Ruolo della Pedologia nella Pianificazione e Gestione del Territorio". Cagliari, Italy.

Dazzi C, 2007. Environmental features and land use of Etna (Sicily - Italy). In: Ò. Arnalds, F. Bartoli, P. Buurman, H. Òskarsson, G. Stoops, E. Garcia-Rodeja (Eds.), Soils of volcanic regions in Europe. Springer, Berlin, Germany, pp. 629-644.

Dazzi C, Galati A, Crescimanno M, Lo Papa G, 2019. Pedotechnique applications in large-scale farming: Economic value, soil ecosystems services and soil security. Catena 181:104072.

Dazzi C, Lo Papa G, 2013. Soil threats. In: E. Costantini, C. Dazzi (Eds.), The Soils of Italy. Springer, Milan, Italy.

Dazzi C, Lo Papa G, 2016. Taxonomic and environmental implication of pedotechnique in large scale farming. Int. Soil Water Conserv. Res. 4:137-41.

Dazzi C, Lo Papa G, 2019. Soil genetic erosion: New conceptual developments in soil security. Int. Soil Water Conserv. Res. 7:317-24.

Dazzi C, Lo Papa G, Palermo V, 2009. Proposal for a new diagnostic horizon for WRB Anthrosols. Geoderma 151:16-21.

EEA (European Environment Agency), 2002. Europe's biodiversity - biogeographical regions and seas. EEA report no 1/2002. Available from: http://www.eea.europa.eu/publications/report 2002_0524_154909/\#

EEA (Eüropean Environment Agency), 2008. Biogeographical regions, Europe. Available from: http://www.eea. europa.eu/data-and-maps/data/ds_resolveuid/3B2B7DDA4584-4963-8D93-A533D3C830DF

Faber JH, van der Pol JJC, 2006. Soil quality and ecosystem services: a land use perspective. In Proceedings of the 1st Open NoMiracle Workshop. Verbania, Italy, June 2006. Available from: http://edepot.wur.nl/42918 Accessed: 23 November 2019.

Garcia-Ruiz JM, 2010. The effects of land uses on soil erosion in Spain: A review. Catena 81:1-11.

Ibáñez JJ, Zinck JA, Dazzi C, 2013. Soil geography and diversity of the European biogeographical regions. Geoderma 192:142-53.

INFC, 2005. Inventario Forestale Nazionale. Available from: https://www.sian.it/inventarioforestale/jsp/01 tabelle_superficie.jsp 
ISPRA, 2015. Valori climatici normali di temperature e precipitazione in Italia. In: ISPRA (Ed.), Stato dell'Ambiente $55 / 2014$.

ISPRA, 2018. Annuario dei dati ambientali 2018: Agricoltura e Selvicoltura. Available from: https://annuario.isprambiente. $\mathrm{it} / \mathrm{sites} / \mathrm{default} /$ files/pdf/2018/versione-integrale/01 Agricoltura.pdf

James BRJ, Blum WEH, Dazzi C, 2014. Bread and soil in ancient Rome: a vision of abundance and an ideal of order based on wheat, grapes, and olives. In: G.J. Churchman, E.R. Landa (Eds.), The soil underfoot: infinite possibilities for a finite resource. CRC Press, Boca Raton, FL, USa, pp. 153-174.

Jenny H, 1941. Factors of soil formation a system of quantitative pedology. Dover Publications, New York, USA, 281 p.

Landi R, 1984. Sistemazioni collinari. L'Italia Agricola 117:12242.

Landi R, 1989. Revision of land management systems in Italian hilly areas. In: U. Schwertmann, R.J. Rickson, K. Auwerswald (Eds.), Soil erosion protection measures in Europe. Soil Technology Series 1. Catena Werlag, Cremlingen, Germany.

Lo Papa G, Palermo V, Dazzi C, 2011. Is land-use change a cause of loss of pedodiversity? The case of the Mazzarrone study area, Sicily. Geomorphology, 135:332-42.

Lo Papa G, Vittori Antisari L, Vianello G, Dazzi C, 2018. Soil interpretation in the context of anthropedogenic transformations and pedotechniques application. Catena 166:240-8.

Niccoli V, 1905. Meccanica agraria. Hoepli, Milano, Italy, pp. XII +410 .

Piccarreta M, Capolongo D, Boenzi F, Bentivenga M, 2006. Implications of decadal changes in precipitation and land use policy to soil erosion in Basilicata, Italy. Catena 65:138-51.

Rifkin J, 2000. The age of access: the new culture of hypercapitalism, where all of life is a paid-for experience. Putnam Publishing Group, New York, NY, USA, pp. 312.

Sereni E, 1986. Storia del paesaggio agrario italiano. Editori Laterza, Bari, Italy.

Serpieri A, 1948. La bonifica nella storia e nella dottrina. Edizioni Agricole, Bologna, Italy.

SSS (Soil Survery Staff), 2014. Keys to Soil Taxonomy, $12^{\text {th }}$ edition. USDA-Natural Resources Conservation Service. Washington, DC, USA.

Todorovic M, Caliandro A, Albrizio R, 2007. Irrigated agriculture and water use efficiency in Italy. pp 101-136 In: N. Lamaddalena, M. Shatanawi, M. Todorovic, C. Bogliotti, R. Albrizio (Eds.), Water use efficiency and water productivity: WASAMED project. Bari: CIHEAM. (Options Méditerranéennes: Série B. Etudes et Recherches; n. 57). 4. WASAMED (WAter SAving in MEDiterranean agriculture) Workshop, 2005/09/30-2005/10/04, Amman (Jordan). Available from: http://om.ciheam.org/om/pdf/b57/0080 0782.pdf

van der Knijf, Jones RJA, Montarella L, 2000. Soil Erosion Risk Assessment Italy. European Commission Directorate General JRC Joint Research Centre Space Applications Institute European Soil Bureau. Available from: https://www.unisdr. org/files/1581_ereurnew2.pdf

Zdruli P, Calabrese J, Ladisa G, Otekhile A, 2014. Impacts of land cover change on soil quality of manmade soils cultivated with table grapes in the Apulia Region of south-eastern Italy. Catena 121:13-21. 